\title{
Improvement of Health Interference Science Learning Result on Blood Circular Organs Through The Learning Video in Class V Students
}

\author{
Kasmini \\ Universitas Sebelas Maret \\ asmipati85@gmail.com
}

\author{
Article History \\ accepted 01/11/2020
}

approved 08/11/2020

published $15 / 11 / 2020$

\begin{abstract}
The background of this research problem is that teachers have not been able to maximize the use of media, especially learning media. This raises various problems for students such as students who are less interested in paying attention to the explanations given by the teacher, students look bored, and in the end students are less active in participating in the teaching and learning process in class and the science learning outcomes of grade $V$ students of SDN Kedalon 01 are low. This study aims to improve student science learning outcomes and describe the use of instructional media in accordance with learning objectives. This type of classroom action research consists of 2 cycles, each cycle consisting of 1 meeting. The research subjects of the fifth grade students of SD N Kedalon 01 were 21 students. The data collection instrument used tests and non-tests. The research instrument was in the form of multiple choice test questions, observation sheets and observations. The results showed an increase in student learning outcomes. The increase in student learning outcomes seen from the classical average value, in cycle I was $76.19 \%$, and cycle II increased to $86 \%$, and cycle III increased to $90 \%$. So the instructional video media can improve students' mathematics learning outcomes. Teachers can apply instructional video media to improve science learning outcomes. Teachers must be able to apply learning models and media that can increase interest and motivation of students in learning.
\end{abstract}

Keywords: Learning Media, Science and Science Learning Outcomes

\begin{abstract}
Abstrak
Latar belakang dari masalah penelitian ini adalah guru yang belum dapat memaksimalkan penggunaan media, utamanya media pembelajaran. Hal ini menimbulkan berbagai masalah bagi siswa seperti siswa kurang tertarik memperhatikan penjelasan yang disampaikan guru, siswa terlihat bosan, dan pada akhirnya siswa kurang aktif dalam mengikuti proses belajar mengajar di kelas dan hasil belajar IPA siswa kelas V SDN Kedalon 01 menjadi rendah. Penelitian ini bertujuan untuk meningkatkan hasil belajar IPA siswa dan mendeskripsikan pemanfaatan media pembelajaran sesuai dengan tujuan pembelajaran. Jenis penelitian tindakan kelas ini terdiri dari 2 siklus, setiap siklus terdiri dari 1 kali pertemuan. Subjek penelitian siswa kelas V SD N Kedalon 01 sebanyak 21 siswa. Instrumen pengumpulan data menggunakan tes dan non tes. Instrumen penelitian berupa soal tes pilihan ganda, lembar pengamatan dan observasi. Hasil penelitian menunjukkan peningkatan hasil belajar siswa. Peningkatan hasil belajar siswa dilihat dari nilai rata-rata klasikal, pada siklus I adalah $76,19 \%$, dan siklus II meningkat menjadi $86 \%$, dan siklus III naik menjadi $90 \%$. Jadi media video pembelajaran dapat meningkatkan hasil belajar matematika siswa. Guru dapat menerapkan media video pembelajaran untuk meningkatkan hasil belajar IPA. Guru harus dapat menerapkan model dan media pembelajaran yang mampu meningkatkan minat dan motivasi peserta didik dalam belajar.

Kata kunci: Media Pembelajaran,IPA dan Hasil Belajar IPA
\end{abstract}

Social, Humanities, and Education Studies (SHEs): Conference Series p-ISSN 2620-9284 https://jurnal.uns.ac.id/shes e-ISSN 2620-9292

This work is licensed under a Creative Commons Attribution-ShareAlike 4.0 International License. 


\section{PENDAHULUAN}

IPA pada hakikatnya adalah ilmu untuk mencari tahu, memahami alam semesta secara sistematik dan mengembangkan pemahaman ilmu pengetahuan tentang gejala alam yang dituangkan berupa fakta, konsep, prinsip, dan hukum yang teruji kebenarannya. Namun, IPA bukan hanya merupakan kumpulan pengetahuan berupa fakta, konsep, prinsip, melainkan suatu proses penemuan dan pengembangan. Oleh karena itu untuk mendapatkan pengetahuan harus melalui suatu rangkaian kegiatan dalam metode ilmiah serta menuntut sikap ilmiah. Definisi tentang IPA (sains) telah banyak dikemukakan, antara lain menurut Supriyadi (2010: 2), para ilmuwan sepakat bahwa IPA adalah suatu bentuk metode yang berpangkal pada pembuktian hipotesa. Sebagian filosof menyatakan bahwa pada hakikatnya IPA adalah jalan untuk mendapatkan kebenaran dari apa yang telah kita ketahui. Dalam Pusat Kurikulum (2006: 4), IPA berkaitan dengan cara mencari tahu tentang alam secara sistematis, sehingga IPA bukan hanya penguasaan kumpulan pengetahuan yang berupa fakta-fakta, konsep-konsep, atau prinsipprinsip saja tetapi juga merupakan suatu proses penemuan. Trianto (2011: 136-137) menyatakan pada hakikatnya IPA dibangun atas dasar produk ilmiah, proses ilmiah, dan sikap ilmiah. Dalam sumber yang sama dinyatakan juga bahwa IPA adalah suatu kumpulan teori yang sistematis, penerapannya secara umum terbatas pada gejala-gejala alam, lahir dan berkembang melalui metode ilmiah seperti observasi dan eksperimen serta menuntut sikap ilmiah seperti rasa ingin tahu, terbuka, jujur, dan sebagainya.

Berdasarkan observasi di kelas V SDN Kedalon 01, hasil belajar IPA masih rendah. Hasil wawancara terhadap guru kelas $\mathrm{V}$, hal tersebut diakarenakan kurangannya dia dalam memvariasikan media pembalajaran yang digunakan sehingga siswa cenderung bosan, kurang antusias dan kurang aktif dalam belajar IPA.

Tujuan peneltian adalah : (1) Meningkatkan Hasil Belajar IPA Materi Gangguan Kesehatan Pada Organ Peredaran Darah Melalui Video Pembelajaran Pada Siswa Kelas V SDN Kedalon 01. (2) Mendeskripsikan Hasil Belajar IPA Materi Gangguan Kesehatan Pada Organ Peredaran Darah Melalui Video Pembelajaran Pada Siswa Kelas V SDN Kedalon 01

Manfaat teoritis ini adalah Melalui penerapan media video pembelajaran diharapkan dapat wawasan dan keilmuan guru sehingga dapat meningkatkan kualitas pembelajaran serta dapat memberikan manfaat bagi perkembangan dunia pendidikan. Manfaat praktis : (1) bagi siswa meningkatnya hasil belajar siswa untuk materi ganguan kesehatan peredaran darah muatan pelajaran IPA, Meningkatnya keaktivan siswa dalam muatan pembelajaran IPA. (2) Bagi Guru: Guru dapat menciptakan proses belajar yang menyenangkan dan bermakna bagi siswa, meningkatnya kreativitas guru untuk menciptakan berbagai macam media pembelajaran sesuai tuntutan abad 21, termotivasi untuk mengembangkan metode mengajar yang lebih bervariasi dengan inovasi pengembangan media pembelajaran IPA, (3) Bagi Sekolah: sebagai sarana untuk menyelesaikan masalah pembelajaran sehingga dapat meningkatkan hasil belajar siswa, sebagai motivasi bagi guru lain untuk bersama-sama melakukan pengembangan media pembelajaran.

IPA pada hakikatnya adalah ilmu untuk mencari tahu, memahami alam semesta secara sistematik dan mengembangkan pemahaman ilmu pengetahuan tentang gejala alam yang dituangkan berupa fakta, konsep, prinsip, dan hukum yang teruj kebenarannya. Namun, IPA bukan hanya merupakan kumpulan pengetahuan berupa fakta, konsep, prinsip, melainkan suatu proses penemuan dan pengembangan.

Menurut Sukiman (2012: 184-191) Media video merupakan media yang mampu menampilkan gambar sekaligus suara dalam waktu bersamaan. Sedangkan menurut Munadi (2013: 154) video pembelajaran merupakan video yang bersifat interaktif tutorial membimbing peserta didik (siswa) untuk memahami sebuah materi melalui visualisasi. Kelebihan media video pembelajaran menurut Munadi (2013: 127) diantaranya mengatasi keterbatasan jarak dan waktu, video dapat diulangi bila perlu untuk menambah kejelasan, pesan yang disampaikannya cepat dan mudah diingat; mengembangkan pikiran dan pendapat para siswa, mengembangkan 
imajinasi siswa, memperjelas hal-hal yang abstrak dan memberikan gambaran yang lebih realistik, dan sangat kuat mempengaruhi emosi seseorang.

Langkah-langkah pemanfaatan video dalam proses pembelajaran menurut Munadi (2013: 127-128) yaitu : (1) Program video harus dipilih agar sesuai dengan tujuan pembelajaran. (2) Guru harus mengenal program video yang tersedia dan terlebih dahulu melihatnya untuk mengetahui manfaatnya bagi pelajaran (3) Sesudah program video dipertunjukkan, perlu diadakan diskusi, yang juga perlu dipersiapkan sebelumnya. Siswa melatih diri untuk mencari pemecahan masalah, membuat dan menjawab pertanyaan (4) Adalakanya program video tertentu perlu diputar dua kali atau lebih untuk memperhatikan aspek-aspek tertentu (5) Agar siswa tidak memandang program video sebagai media hiburan belaka, sebelumnya perlu ditugaskan untuk memperhatikan bagian-bagian tertentu (5) Sesudah itu dapat di test berapa banyakkah yang dapat mereka tangkap dari program video itu.Berdasarkan pendapat ahli dapat disimpulkan media video pembelajaran adalah bagian dari media audio visual yang dapat digunakan untuk memutar gambar sekaligus suara dalam waktu yang sama. Media video pembelajaran ini akan digunakan untuk menunjang proses penyampaian materi atau tugas yang diberikan guru kepada siswa dalam proses pembelajaran.

Menurut Rahmayanti, (2016 : 213) menyebutkan bahwa hasil belajar ialah suatu hal yang dicapai siswa yang merupakan hasil dari proses pembelajaran yang telah diterimanya di sekolah dan dapat diukur dengan alat atau tes tertentu. Tujuan dari hasil belajar adalah sebagai alat ukur dalam proses pembelajaran yang telah dilakukan. Evaluasi hasil belajar adalah suatu cara yang dapat digunakan untuk mengetahui tingkat keberhasilan kegiatan belajar yang dilakukan.

\section{METODE}

Penelitian ini merupakan penelitian tindakan kelas (PTK). Penelitian ini dilakukan dimaksudkan kepada perbaikan dalam proses belajar mengajar di kelas. Perbaikan dalam penelitian tindakan kelas ini meliputi perbaikan sistem, cara kerja, proses, isi, dan situasi pembelajaran. Pelaksanaan penelitian ini terdiri atas 3 siklus, setiap siklus terdiri 1 tahap yang lazim dilalui, yaitu perencanaan tindakan, pelaksanaan tindakan, pengamatan atau observasi, dan refleksi. Prosedur tersebut dilakukan secara berulang sampai perbaikan atau peningkatan hasil belajar tercapai. Desain bagan dalam penelitian ini menurut Arikunto (2010: 27) adalah sebagai berikut

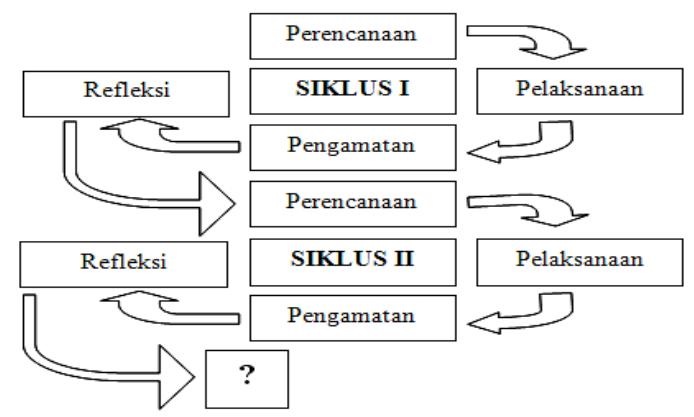

\section{Bagan 1 Skema alur penelitian}

Dalam penelitan ini terdiri dari 2 var iabel: 1) variabel bebas $(X)$ yaitu media video pembelajaran dan variabel terikat (Y), yaitu hasil belajar IPA siswa kelas $V$ SD N Kedalon 01. Peneliti melakukan pengumpulan data dengan teknik tes, observasi, dan dokumentasi. Indikator hasil dalam penelitian ini yaitu meningkatnya hasil belajar IPA melalui media video pembelajaran, siswa secara signifikan mengalami ketuntasan belajar individual $\leq 70$ dan mengalami ketuntasan belajar secara klasikal sebesar $\leq 86 \%$. 
Hasil Analisis Data

\section{HASIL DAN PEMBAHASAN}

Bab ini memaparkan hasil analisis dan data penelitian, tentang hasil belajar IPA KD 3.4 Memahami organ peredaran darah dan fungsinya pada hewan dan manusia serta cara memelihara kesehatan organ peredaran darah manusia. KD 4.4 Menyajikan karya tentang organ peredaran darah pada manusia pada kelas $\mathrm{V}$ SDN Kedalon 01 menggunakan media video pembelajaran. Hasil belajar dari siklus I, siklus II, dan siklus III dapat dilihat pada tabel 2.

\section{Tabel 1}

Rekapitulasi Hasil Belajar IPA Siswa Kelas V SDN Kedalon 01 Kondisi Siklus I, Siklus II, dan Siklus III

\begin{tabular}{|c|c|c|c|c|c|c|c|c|}
\hline \multirow[b]{2}{*}{ No } & \multirow{2}{*}{$\begin{array}{c}\text { Ketuntasan } \\
\text { belajar }\end{array}$} & Nilai & Siklus I & \multirow{2}{*}{$(\%)$} & $\begin{array}{c}\text { Siklus } \\
\text { II }\end{array}$ & \multirow{2}{*}{$(\%)$} & Siklus III & \multirow{2}{*}{$(\%)$} \\
\hline & & $\begin{array}{c}\text { Jumlah } \\
\text { siswa }\end{array}$ & $\begin{array}{c}\text { Jumlah } \\
\text { siswa }\end{array}$ & & $\begin{array}{c}\text { Jumlah } \\
\text { siswa }\end{array}$ & & $\begin{array}{c}\text { Jumlah } \\
\text { siswa }\end{array}$ & \\
\hline 1 & Tuntas & $\leq 70$ & 16 & 76,19 & 18 & 86 & 19 & 90 \\
\hline 2 & $\begin{array}{c}\text { Tidak } \\
\text { Tuntas }\end{array}$ & $<70$ & 5 & 13,81 & 5 & 14 & 2 & 10 \\
\hline \multicolumn{3}{|c|}{ Jumlah } & 21 & \multirow{2}{*}{100} & 21 & \multirow{2}{*}{100} & 21 & \multirow{2}{*}{100} \\
\hline \multicolumn{3}{|c|}{ Nilai Rata-rata } & 77,14 & & 79 & & 83,33 & \\
\hline
\end{tabular}

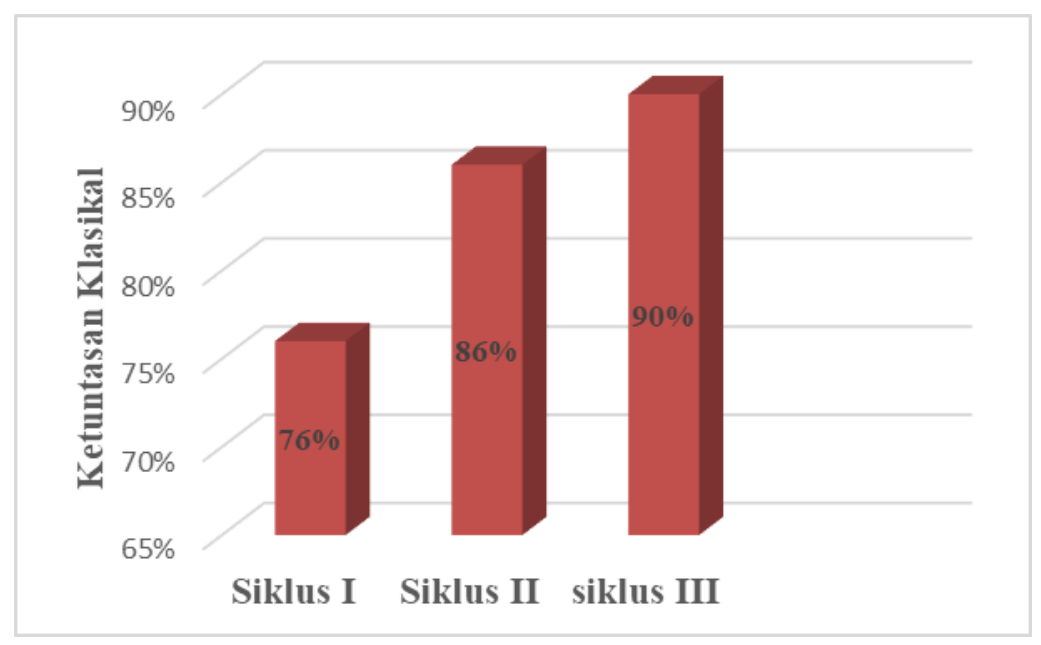

Gambar 1. Hasil Belajar IPA Siswa Kelas V SDN Kedalon 01

Berdasarkan gambar 1 dapat dijelaskan perbandingan hasil belajar setiap siklus. Dari hasil belajar siklus III telah memenuhi indi- kator yang ditentukan (ketuntasan belajar siswa $\leq$ $80 \%$ ) sehingga tidak perlu dilakukan penelitian tindakan lagi. 
Hasil observasi yang dilakukan di siklus I, guru masih belum terampil dalam mengondisikan siswa dalam menyelesaikan permasalahan yang diberikan oleh guru. Guru juga kurang dapat membimbing siswa yang dilakukan, terlihat siswa masih belum aktif dalam menyelesaiakan masalah. Dari Dari kekurangan- kekurangan tersebut, maka keterampilan guru dalam menguasai media pembelajaran yang digunakan serta menguasai kelas harus lebih ditingkatkan lagi, dan diperlukanlah suatu bimbingan yang optimal oleh guru saat siswa memecahkan masalah, sehingga siswa tidak lagi kebingungan ataupun merasa jenuh dengan kegiatan pembelajaran yang dilakukan. Selain itu guru dapat lebih terampil lagi dalam mengaktifkan siswa dalam menghidupkan suasana kelas yang lebih bermakna, sehingga mempengaruhi tingkat pemahaman siswa.

Hasil observasi siklus II , keterampilan guru dalam memanfaatkan media pembelajaran sudah ada peningkatan dibandingkan dengan yang siklus I. Disamping itu guru juga sudah melaksanakan pembelajaran daring secara interaktif. Hasil observasi siswa di siklus II menunjukkan adanya perubahan kearah yang lebih baik. Siswa bisa menyesuiakan dengan pembelajaran daring yang menggunakan media pembelajaran, sehingga bisa menyelesaikan masalah terhadap soal yang diberikan. Keaktifan siswa sudah mulai nampak, salah satunya ketika ada pertanyaan yang diberikan oleh guru, siswa mulai menjawab dan tidak ragu.

Sedangkan untuk siklus III, hasil observasi keterampilan guru dalam memanfaatkan media pembelajaran sudah lebih luwes, dan bisa mengondisikan siswa dengan baik. Hal ini tampak ketika guru mulai pembelajarn daring menggunakan media pembelajaran tidak lagi kerepotan dana lebih tertata dengan baik. Kelas onlinepun Nampak lebih aktif dan interaktif. Hasil observasi siswa di siklus III menunjukkan perubahan perilaku siswa yang leabih aktif dan pembelajaran menyenangkan. Siswa sudah terbiasa dengan pembelajaran daring, sehingga lebih terkontrol dan siswa mampu menyelesaikan masalah yang ada dalam soal. Keaktifan siswa lebih tampak, seperti lebih aktif dan tidak malu-malu lagi dalam menjawab pertanyaan-pertanyaan dari guru.

Kegiatan siklus III dapat disimpulkan bahwa permasalahan yang muncul di siklus Idan II telah dapat diatasi dengan baik. Dengan ketercapaian target yang telah ditentukan peneliti, maka dari itu sudah tidak diperlukan lagi untuk masuk ke siklus selanjutnya. Dan penelitian cukup berhenti di siklus II ini.

\section{PEMBAHASAN}

Berdasarkan hasil analisis data penelitian tindakan, terdapat peningkatan hasil belajar yang terjadi dari kondisi siklus I, siklus II, dan siklus III. Dalam penelitian ini bukan hanya sekedar peningkatan nilai siswa saja yang terjadi, namun sikap siswa yang lebih aktif dari sebelum penelitian/pra siklus juga nampak pada pembelajaran yang dilakukan setiap pertemuannya. Sikap aktif itu timbul dikarenakan siswa dituntut untuk dapat menyelesaikan suatu permasalahan terkait materi pecahan yang diberikan melalui soal cerita.

Hasil penelitian ini mempunyai perbedaan dengan peneltian yang dilakukan oleh peneliti sebelumnya. Dalam penelitian inipenerapan pemanfaatan media pembelajaran dapat menambah antusias siswa dalam pembelajaran yang berbeda dengan yang sebelumnya. Siswa mendapat pengalaman yang lebih, karena bisa melihat tampilan materi pembelajaran 
secara langsung secara audio visual. Sehingga pembelajaran yang dirasakan siswa lebih bermakna.

Dengan adanya penelitian ini memberikan implikasi baik secara teoritis maupun secara praktis.

1. Implikasi Teoritis

Penerapan media video pembelajaran dalam penelitian ini disesuiakan dengan karakterisistik siswa, yaitu siswa mendapat pengalaman belajar yang lebih bermakana dengan cara audio visual.

2. Implikasi Praktis

Penggunaan media pembelajaran ini, harus diimbangi dengan keterampilan guru dalam penggunaan tekhnologi yang berupa internet. Sehingga guru akan lebih mudah untuk mendapatkan media video pembelajaran yang diperlukan, yaitu dengan pencarian di youtobe, atau dengan mengkreasi sendiri.

\section{SIMPULAN}

Berdasarkan hasil penelitian tindakan kelas yang dilaksanakan pada siswa kelas $V$ SDN Kedalon 01 Kecamatan Batangan Kabupaten Pati bahwa media video pembelajaran dapat meningkatkan hasil belajar IPA siswa kelas V SDN Kedalon 01 semester gasal tahun ajaran 2020/2021.

\section{DAFTAR PUSTAKA}

Arikunto, Suharsimi. 2010. Prosedur Penelitian Suatu Pendekatan Praktik. Jakarta: Rineka Cipta. Aqip, Zaenal. 2009. Penelitian Tindakan Kelas Untuk Guru SMP dan SMA. CV

Yrama Widya: Bandung

Arsyad, Azhar. 2013. Media Pembelajaran. Jakarta: Rajawali Pers

https://id.wikipedia.org

Lapono, Nabisi. 2008. Belajar dan Pembelajaran SD. Jakarta: Depdiknas

Munadi, Yudhi. 2013. Media Pembelajaran; Sebuah Pendekatan Baru. Jakarta: GP Press Group

Prastowo, Andi. 2011. Panduan Kreatif Membuat Bahan Ajar Inovatif. Yogyakarta: DIVA

Press Wardani, IGAK . Wihardit, Kuswaya. 2012. Penelitian tindakan kelas. Tanggerang Seltan: Universitas Terbuka

Sukiman. 2012 Pengembangan Media Pembelajaran. Yogyakarta: Pedagogia. 
